\title{
Kadın Öğretmenlerde İ̧̧-Yaşam Dengesi ve İş Performansı Arasındaki İlişkinin İncelenmesi
}

\author{
Examining the Relationship Between Work-Life \\ Balance and Job Performance of Female Teachers
}

Şule Polat*

\begin{abstract}
$\ddot{O ̈ z}_{\mathbf{z}}$
Bu araştırmada, kadın öğretmenlerin iş-yaşam dengesi ile iş performansı ilişkisi incelenmiştir. Çalışmanın evrenini Ankara ili merkez ilçelerinde bulunan resmi ortaokullarda 2016-2017 eğitim öğretim yılında görevli olan toplam 11.106 kadın öğretmen oluşturmuştur. Araştırmanın örneklemini de evreni temsilen tesadüfì seçilen 322 kadın öğretmen oluşturmuştur. Araştırma verileri "İş-Yaşam Dengesi Ölçeği” ve "Bireysel İş Performansı Ölçeği" ile toplanmıştır. Bulgular iş-yaşam dengesi ile iş performansı arasında ilişki olduğunu ortaya koymuştur. İş performansı ile iş-yaşam dengesinin "İ̧̧-Yaşam Uyumu", "Yaşamı İhmal Etme" ve "Yaşamın İşten İbaret Olması" boyutları arasında pozitif yönlü ilişki olduğu görülmüştür. Regresyon analizi sonuçları ise iş-yaşam dengesinin "Yaşamı İhmal Etme" ve "Kendine Zaman Ayırma" boyutlarının iş performansının anlamlı yordayıcıları olduğunu göstermiştir. Araştırma sonucunda iş-yaşam dengesini kurabilen kadın öğretmenlerde iş performansının arttığı görülmüştür.
\end{abstract}

\section{Abstract}

This study examines the relationship between work-life balance and job performance among female teachers. The population of this study

* Dr. Milli Eğitim Bakanlığı, Öğretmen, Ankara, Türkiye, mail: sule.polat@ yahoo.com, orcid.org/0000-0001-5469-5758

\footnotetext{
Başvuru: 24 Temmuz 2018

This work is licensed under the Creative Commons Attribution 4.0 International License.

Kabul: 10 Kasım 2018

Cite this article as: Polat, Ş. (2018). Kadın Öğretmenlerde Iş-Yaşam Dengesi ve Iş Performansı Arasındaki Iliş̧kinin Incelenmesi, Kadem Kadın Araştırmaları Dergisi. DOI: $10.21798 /$ kadem.2019249085 Cilt 4, Sayı 2, 187-205.
} 
consists of 11,106 female teachers working in public secondary schools in the central districts of the Turkish capital of Ankara over the 20162017 academic year. The sample consists of 322 randomly selected female teachers representing the universe. Research data was compiled using both the Work-Life Balance Scale and Individual Job Performance Scale. The findings revealed a relationship between work-life balance and job performance. There was a positive correlation between job performance and "Work-Life Harmony", "Neglecting Life" and "Over-commitment to Work" dimensions of the work-life balance. The regression analysis results showed that "Neglecting Life" and "Making Time for Personal Activities" dimensions of work-life balance were significant predictors of job performance. As a result, it can be concluded that worklife balance increases female teachers' job performance.

Anahtar Kelimeler: İş-Yaşam dengesi, iş performansı, ortaokul, öğretmen, kadın

Keywords: Work life balance, job performance, secondary school, teacher, women

\section{Extended Abstract}

As teaching is a stressful occupation and women form a larger percentage of teaching staff compared to other professions, work-life balance is of utmost importance. Moreover, as a direct consequence of the manner of work that teaching entails and the diversity in the assumed roles, the work-life conflict is a significant factor in the way teaching is performed. Previous studies show that female teachers are confronted with significantly larger obstacles in creating the necessary work-life balance and harmony between their professional and private responsibilities. The scope of this study thus covers the relationship between work-life balance and job performance of female teachers.

\section{Purpose}

- What are the views of female teachers about work-life balance and job performance?

- Is there a relationship between the work-life balance of female teachers and their job performance?

- Is job performance a meaningful predictor of work-life balance?

\section{Method}

The study is based on an academic survey that investigated the life-work balance and job performance of female teachers, with the data collected having been analyzed using quantitative techniques. 


\section{Population}

The population of this study consists of 11,106 female teachers who worked in public secondary schools in Ankara's central districts over the 2016-2017 academic year. The study made use of samples taken from this population. The sample size table was used in determining the sample size of this study. As a result, 262 female teachers were seen as representative of the population, with a reliability of .05 and a margin of error of $10 \%$ (Balc1, 2005). However, as a precaution against possible problems that could take place while returning the survey, the questionnaire was handed to 400 teachers, 322 of whom returned in a state that was appropriate to be analyzed.

\section{Data Collection Tools}

\section{Work-Life Balance Scale}

The "Work-Life Balance Scale" developed by Apaydın (2011) was used to determine the perception of female teachers toward the work-life balance. The questions were posed on a one dimensional Likert-type scale (strongly disagree, disagree, partly agree, agree, strongly agree). The total reliability of the study was calculated as .74. The four dimensional structure of work-life balance was confirmed and the items gathered had the same dimensions as in the original. The fit index values of the model obtained through the confirmatory factor analysis of the Work-Life Balance Scale demonstrates good harmony in the model.

\section{Individual Job Performance Scale}

To determine the perception levels of the participants' individual job performance, the study utilizes "the Individual Job Performance Scale" developed Kirkman and Rosen (1999), which was adapted to Turkish by Gürbüz, Erkuş and Sığrı (2010), who also carried out its validity and reliability studies. The scale was, again, a one dimensional five-point Likert-type scale (strongly disagree, disagree, partly agree, agree, strongly agree). The Cronbach Alpha coefficient was determined as .73. The DFA was used to structural validity of the scale. The calculations confirmed the one dimensional structure of the scale.

\section{Findings}

The average "Job Performance" score of the subjects was "high," while their average "Neglecting Life," "Making Time for Personal Activities" and "Over-commitment to Work" scores were "medium."

There appeared to show a low level positive and statistically significant relationship between "Job Performance" and "Work-life Harmony;" a positive, medium level and significant relationship with the "Neglecting Life;" and a positive, low level and significant relationship with the "Over-Commitment to Work." 
There is a medium level and statistically significant relationship between the dimensions of the "Work-Life Balance Scale." The findings show that $13 \%$ of job performance is explained by the dimensions of "Work-Life Balance." According to the standardized regression coefficient (B), the dimensions of "Neglecting Life" and "Making Time for Personal Activities" are significant indicators of job performance.

\section{Conclusion and Suggestions}

This study shows that female teachers experience difficulties in maintaining a satisfying work-life balance and this, in turn, affects their job performance. Within this framework, they seem to find themselves stuck between their professional and private responsibilities.

To strike a fulfilling work-life balance, increase job performance and be more effective in their jobs, female teachers need optimized course loads, fewer students in classes, a support system for children with special needs, increased time allocated to planning and preparatory work and less burdens unrelated to instructing, such as administrative and playground duties.

\section{Giriş}

İş-yaşam dengesi en genel ifadesiyle, bireyin işi, ailesi ve kişisel yaşamı arasındaki uyumdur. Dolayısıyla bireylerin iş, aile ve kişisel amaç, hedef ve talepleri arasındaki dengeyi ifade etmektedir (Polat, 2017, s. 54). Genel olarak kişinin rolleri ve sorumlulukları arasında denge kurabilmesi, daha az çatışmayla daha mutlu bir yaşam sürdürebilmesi olarak da tanımlanmaktadır (Koray, 2016). Yapılan araştırmalar iş-yaşam dengesine sahip kişilerin ruh halinin daha iyi ve iş performanslarının daha yüksek olduğunu göstermektedir (Erben ve Ötken, 2014).

İ̧̧-yaşam dengesi arayışı, bireyin iş ve yaşam alanlarını yönetmesiyle ilgili yaşadığı ikilemlerden kaynaklanmaktadır. Dolayısıyla; bu alanda yapılan çalışmalarda hem sosyal hem ekonomik hem de iş dünyasındaki gelişmeler yakından takip edilmektedir. Bu yönüyle iş-yaşam dengesi, kapsamı sürekli değişen ve genişleyen bir kavramdır. 60'lı yıllardan itibaren kadınların çalışma hayatına katılmasıyla "çalışan anneler", "çift gelirli aileler", "iş-aile çatışması" gibi unsurlar ile sonraki dönemlerde "küreselleşme", "örgütlerin yeniden yapılandırılması”, "serbestleşme”, "teknolojiye uyum”, “7/24 hizmet sunma” 
gibi pek çok faktör, bireyler ve örgütler üzerindeki etkilerinin yanı sıra, bu konuda yapılan çalışmalar üzerinde de belirleyici olmuştur (Lewis ve diğerleri, 2007, s. 360).

1970'li yıllarda çok sayıda kadının iş gücüne katılımıyla iş-yaşam dengesi kavramı ele alınmaya başlanmış, işin anlamı ile iş görenin algılarında değişikliğe neden olmuştur. Artık ev içi iş yükü ve çocuk bakımı gibi konular, yalnızca bireyi değil, değişen iş ortamlarını da ilgilendiren hususlar olarak görülmeye başlanmış ve iş-yaşam dengesi kavramı ortaya atılmıştır (McIntosh, 2003). Hane-işyeri ayrışması, kadınların iş gücüne katılımının artması ve bu durumun sonuçlarının önemli hale gelmiş olması bunda etkili olmuştur. Günümüz iş ve yaşam koşullarında cinsiyet boyutu iş-yaşam dengesinin önemli bir bileşenidir. Ancak iş-yaşam dengesi yalnızca kadınlara yönelik bir sorun alanı olmayıp, belirleyicilerine bağlı olarak kişiden kişiye farklılık gösterebilen ve kapsamı sürekli değişip genişleyen bir kavramdır.

İş-yaşam dengesi kavramı, "iş" ve “iş dışı yaşam” bileşenlerini etkileyebilecek çeşitli faktörler tarafından belirlenmektedir. Guest (2002) tarafindan geliştirilen bir modele göre; iş-yaşam dengesinin belirleyicileri örgütsel ve bireysel faktörler olmak üzere ikiye ayrılmaktadır. Örgütsel faktörler iş talepleri ve kültürü ile ev talepleri ve kültüründen oluşmaktadır. Bireysel faktörler ise; işe uyum, kişilik, enerji, kişisel kontrol ve başa çıkma, cinsiyet, yaş ve yaşam-kariyer evresidir. Modele göre iş-yaşam dengesinin hem öznel hem nesnel göstergeleri bulunmaktadır. Öznel ölçütler bireyin iş ve yaşamındaki denge ya da dengesizlik hissini ifade etmektedir. Nesnel ölçütler ise, bireyin çalışma saatleri ile iş dışı yaşamındaki boş zamanları ve aile içinde üstlendiği rolleridir (Guest, 2002). Modele göre, iş-yaşam dengesinin sonuç veya etkileri ise; iş ve yaşam doyumu, bireyin ruh ve beden sağlığı, iş ve iş dışı yaşamda gösterdiği performans ile iş ve evdeki diğer kişilerle etkileşimidir.

"Yeni milenyumda iş-yaşam çatışması" adlı raporlarında Duxbury ve Higgins (2003) iş-yaşam dengesinin teorik çerçevesi olarak tanımladıkları bir model geliştirmişlerdir. Bu model iş ve iş dışı taleplerle bireyin demografik özellikleri, iş ve iş dışı belirleyicilerin ilişkilerini ve bunların ortaya çıkardığı iş-yaşam dengesinin birey, aile, 
örgüt ve toplum açısından sonuçlarını ortaya koymaktadır. Bu modele göre iş-yaşam dengesini oluşturan faktörler gücü aşan rol üstlenme, rol zıtlığı, rol taşması ve bakım yüküdür. Zaman ve enerji gerektiren çeşitli aktivite ve rollerin fazlalığı, yani aşırı iş yükü sorumluluklarının tam olarak ve rahat bir şekilde yerine getirilmesini engelleyebilmektedir. Uzun çalışma saatleri, esnek olmayan çalışma programı, ağır iş yükü, iş seyahatleri, iş nedeniyle taşınma gibi durumlar da bir çalışanın aile içindeki rollerini ve işlevlerini tam olarak yerine getirmesini engelleyebilmektedir. Hasta çocuğun bakımı gibi aileyle ilgili özel durumlar da işte dikkat dağıtabilmekte, işe geç kalmaları arttırabilmekte ya da tam tersi evdeki sorunlardan kaçmak için iş görenin tamamen işe odaklanmasına neden olabilmektedir. Benzer bir şekilde, yaşlı ya da engelli aile bireylerinin bakım zorunluluğu da bireylerde stres ve gerginlik yaratabilmektedir (Brown, 2004).

Duxbury ve Higgins (2003) tarafindan geliştirilen modelde, iş ve iş dışı taleplere bağlı olarak diğer değişkenlerin (demografik özellikler, örgütsel ve birey/aile belirleyiciler) de etkisiyle oluşan iş-yaşam dengesi veya dengesizliği; işe ilişkin bağlılık, iş doyumu, iş stresi, işten ayrılma niyeti, örgütün itibarı ve işe devamsızlık durumlarını ortaya çıkarmaktadır. Modelin aileye ilişkin sonuçları uyum, yaşam doyumu, ebeveyn doyumu, pozitif ebeveynlik ve aile bütünleşmesi olarak ifade edilmiştir. Bireye ilişkin sonuçlar ise, stres, depresyon hali, tükenmişlik duygusu, yaşam doyumu ve fiziksel sağlık durumudur. İş-yaşam dengesinin sağlanmasının sosyal sonucu ise, işe devam etme ve ayrılma veya sağlık durumuna bağlı olarak ortaya çıkan sağlık sigortası sisteminden yararlanma durumudur.

İş-yaşam dengesi kavramı alanyazında daha çok iş-yaşam çatışması olarak ele alınmış, bu çerçevede; denge kavramından önce, çatışma kavramı incelenmiştir. Klasik örgüt kuramcıları iş ile yaşam arasındaki etkileşime ilişkin çalışmalar yapmışlardır. Bu çerçevede Elton Mayo, Fritz J. Roethlisberger ve William J. Dickson adlı endüstri psikologları tarafindan 1927 ile 1932 yılları arasında, Hawthorne'da (ABD) bulunan Western Electric Şirketi’nde yapılan çalışmalarda iş ortamında sosyal ve duygusal gereksinimlerin varlığı gündeme gelmiş ve bunların etkisi ortaya çıkarılmıştır. Bu çalışmalar sonucunda, iş 
yerindeki fiziksel koşulların iyileştirilmesi gibi, iş görenin duygusal gereksinimlerin karşılanmasının da verimliliğe olumlu etkide bulunduğu ortaya konmuştur (Küçükusta, 2007).

1950'li yıllardan sonra iş ve iş dışı yaşamın "ayrı dünyalar" olduğuna ilişkin çalışmalar yapılmıştır. İş dışındaki sorunların iş yerinin kapısında bırakılması gerektiğine inanan örgüt kültürü anlayışı ve geleneksel cinsiyet rol dağılımı bu ayırımı daha da güçlendirmiştir. Buna göre, kesin sinırlarla ayrılan söz konusu alanların kendine özgü talepleri ve bu talepler arasında kaçınılmaz bir rekabet söz konusudur. Ancak bu sorun sadece kadınları ilgilendiren bir sorun olarak ele alınmıştır. Sonraki yıllarda, roller ve stres üzerinde yapılan çalışmalar, yeni bir iş-yaşam olgusunu ortaya çıkarmıştır. Bu çerçevede, ev içi sorumluluklarının sadece kadınları ilgilendiren bir konu olmadığı, erkeklerin de ev içi işlere katılımının gerektiği görülmeye başlanmıştır. Öte yandan yapılan çalışmalar, iş ve iş dışı yaşamın tamamen ayrı alanlar olmadığını ve birbirlerini etkilediğini ortaya koymuştur (Kapız, 2002).

İş gücünde çocuklu (bakım yükü olan) kadın iş gören sayısındaki artış, kadın ve erkeklerin iş hayatındaki rollerindeki benzerliklerin artması, yeni aile modellerinin ortaya çıkması, aile içindeki rollere ilişkin daha eşitlikçi tutumların ve erkeğin yaptığı işin aile rollerine etkisinin ön plana çıkması, boşanma oranlarındaki artış ve iş gücü mobilitesindeki artış gibi birçok demografik, ekonomik ve kültürel değişim iş ve iş dışı yaşam arasındaki ilişkilerin araştırılmasına yönelik ilgiyi arttırmıştır. Böylece iki alan arasında başlangıçta pek de fark edilmeyen ilişki, zamanla belirginleşmeye başlamış ve giderek daha titiz bir bakış açısıyla değerlendirilmeyi gerektirmiştir (Kapız, 2002; Savc1, 1999).

Bireyler, örgütler ve toplum açısından önemi giderek artan iş-yaşam etkileşimi; insan kaynakları yönetimi açısından, iş göreni örgütte tutma ve performansını arttırma stratejilerinin önemli unsurlarından birisi olarak ele alınırken, toplum bilimi açısından daha çok aile ve kadın kavramları üzerinden, psikoloji bilimi açısından da daha çok bireylerdeki davranışsal sonuçlara (ruh sağlığı, yaşam doyumu, stres, tükenmişlik vb.) odaklanılarak ele alınmaktadır. 
İş performansı "belirli bir işin yerine getirilmesi ve tamamlanması" (Chiu, 2004, s. 82) veya "belirlenen koşullara göre bir işin yerine getirilme düzeyi veya iş görenin davranış biçimi” (Bingöl, 2006, s. 321) olarak kavramsallaştırılmaktadır. İş performansı, "kişinin işini yerine getirmek için harcadığı tüm çabalar karşısında elde ettiği başarı düzeyi” (Yıldız, Savcı ve Kapu, 2014, s. 111) şeklinde de tanımlanmaktadır. Shmailan (2016) iş performansını etkileyen faktörleri eğitim, uygun kişinin uygun yerde çalışması ve çalışanın iş güvencesinin olması olarak sıralamaktadır. Bu çerçevede; bireyin eğitim ile gelişeceği, buna bağlı olarak çalışacağı örgütte fayda sağlayacağı üzerinde durmakta, buna ek olarak kişilik özellikleri, bireyin beklentileri ile çalışılan örgütün uyumluluğunun önemine değinmektedir.

İş-yaşam dengesi diğer tüm iş görenler açısından önem taşıdığı gibi öğretmenler açısından da önemlidir. Ancak öğretmenlerdeki iş-yaşam dengesinin veya dengesizliğinin etkilerinin başka bireyler üzerindeki etkileri düşünüldüğünde bunun sadece kendileri için değil, tüm toplum için önemli olduğu görülecektir.

Toplumun tüm kesimlerine bilgi aktarma rolü üstlendikleri için öğretmenlerin iş-yaşam dengesi büyük önem taşımakta, öte yandan öğretmenlerdeki iş-yaşam dengesizliği diğer tüm sektörler için zararlı sonuçlar ortaya çıkarmaktadır. Çeşitli çalışmalar, daha fazla başarma isteğinin insanların aşırı çaba göstermelerine ve çalışma sürelerini arttırmalarına, bunun da iş-yaşam dengelerini kaybetmelerine neden olduğunu ortaya koymuştur. İş yaşam dengesinin kaybı iş görenlerde iş doyumunu azaltmakta ve stres düzeylerini arttırmaktadır. Günümüzde öğretmenler de dahil, iş görenlerin en önemli ihtiyacı iş-yaşam dengesinin sağlanması ve sürdürülmesidir. Çünkü iş ve kişisel yaşam arasında sağlanan etkin bir denge, bireyler için daha fazla doyum ve mutluluk anlamına gelmektedir (Saeed ve Farooqi, 2014).

Öğretmenlik mesleği, tatil sürelerinin uzunluğu ve çalışma saatlerinin makul zamanları içermesi gibi nedenler diğer mesleklere oranla iş-yaşam çatışması daha düşük oranda yaşanan bir meslek olarak algılanmaktadır (Cinamon ve Rich, 2002). Buna karşın öğretmenliğin mesleki özellikleri, öğretmenlerden beklenen rol ve 
sorumluluklar dikkate alındığında iş ve yaşam alanlarında denge kurmalarının çok kolay olmadığı bilinmektedir. Bu çerçevede, özellikle görevini iyi yapma konusuna gerekli çabayı gösteren öğretmenin işinde ve vereceği derslere hazırlanmak için evinde harcayacağı zaman ve enerjinin iş dışı yaşamına etkisi veya bunların tersi durumlar gibi nedenlerle sıkıntı çekmeleri de olası görünmektedir (Özkul, 2014).

Öğretmenlik mesleği bazı kesimlerce yaz tatilleri ve çalışma saatlerindeki esneklikler nedeniyle kolay bir meslek olarak algilanmaktadır. Ancak öğretmenlerin karşılaştığı uyumsuz öğrenci davranışları, bürokratik işleri, derse hazırlık çalışmaları, haftalık ders yüklerinin fazla olması, iş dışı yaşamdaki rollerinin (evlenme, çocuk sahibi olma) daha ön plana çıkması gibi nedenlerle ve mesleki gelişim ve öğrenim düzeyini arttırmak üzere eğitim aldıkları dönemlerde iş-yaşam dengesini kurmada daha çok zorlandıkları görülmektedir (Özkul, 2014).

Öğretmenlerin iş-yaşam dengesi, eğitim kurumlarının geliştirilmesi ve başarısı için de önemli bir unsurdur. Modern dünyada öğretim ve öğrenim ortamındaki değişikliklere bağlı olarak öğretmenlerin rollerini sürekli olarak değişmekte ve bu değişimler öğretmenler üzerinde ağır iş baskısı oluşturmaktadır. Bu da öğretmenlerin kişisel yaşamlarını etkilemekte ve öğretmenlerde iş-yaşam dengesizliğine neden olabilmektedir. Day ve diğerleri (2006, s. 260) tarafindan öğretmenlerin iş-yaşam etkileşimi ve iş etkililiği üzerine yapılan araştırmada; "öğretmenlerin iş ve yaşamlarının etkileşim içinde olduğu", "öğretmenin iş etkililiği için kişisel yaşamında iyileştirme ve mesleğinde yatırım yapılmasının gerektiği” bulguları ortaya çıkmıştır. Greenglass ve Burke (1988) tarafından Kanada'da 247 öğretmenin iş-yaşam dengesi üzerine yapılan çalışmada, çocuk sahibi olmanın kadın öğretmenler lehine anlamlı farklılaştığı, erkek öğretmenler için ise anlamlı farklılaşmadığı sonucuna varılmıştır. 2014 yılı başında Kanada Öğretmenler Federasyonu tarafından ilköğretim ve ortaöğretimde görev yapan 8096 öğretmen üzerinde iş stresi ve iş-yaşam dengesine etki eden faktörler tespit edilmeye çalışılmıştır. Araştırma sonucunda ulaşılan temel sonuçlar şunlardır (Froese-Germain, 2014): 
- Öğretmenlerin \%54’ü (kadınlarda bu oran erkeklerden daha yüksek) iş-yaşam dengesini sağlayamadığını belirtmiştir.

- Öğretmenlerin \% 85’i iş-yaşam dengesizliğinin öğretme yeteneklerini etkilediğini (\% 35’i bunun çok önemli düzeyde bir etkisi olduğunu) belirtmiştir.

- Öğretmenler, mesleklerini yürütme koşullarıyla ilişkili en önemli stresin öğrencilerin her birine istedikleri kadar zaman ayıramamadan kaynaklandığını belirtmişlerdir. Bunun dışında bireyselleştirilmiş eğitim programları ve özel eğitim gereksinimleri olan öğrencilerle ilgili konular, meslektaşlarıyla ortak planlama zamanı bulamama, öğrenci çalışmalarının izlenmesi ve değerlendirilmesi için zaman bulamama, müfredatı destekleyecek insan ve maddi kaynak eksikliği ve derse hazırlık zamanı bulamama diğer önemli stres faktörleri olarak belirtilmiştir.

Öğretmenliğin stresli bir meslek olması ve öğretmenlik mesleğinde kadınların diğer mesleklere göre ezici bir çoğunluğa sahip olması, öğretmenlerde iş-yaşam dengesinin önemini arttırmaktadır. Bunun dışında yapılan işin şekli ve üstlenilen rollerdeki çeşitlilikler gibi farklı boyutlar nedeniyle de iş-yaşam çatışması öğretmenlik mesleğinde önemli bir faktördür. Yapılan çalışmalar kadın öğretmenlerin iş-yaşam dengesi kurmada çok zorlandıklarını, iş sorumlulukları ile yaşamları arasındaki uyumu sağlamada güçlük yaşadıklarını göstermektedir. Bu çalışma kapsamında da kadın öğretmenlerin iş-yaşam dengesi ile iş performansı ilişkisi incelenecektir.

\section{Araştırmanın Amacı}

1. Kadın öğretmenlerin iş-yaşam dengesine ve iş performansına ilişkin görüşleri nasıldır?

2. Kadın öğretmenlerin iş-yaşam dengesi ile iş performansları arasında ilişki var mıdır?

3. İş performansı, iş-yaşam dengesinin anlamlı bir yordayıcısı mıdır? 


\section{Yöntem}

Kadın öğretmenlerin iş-yaşam dengesi ile iş performansı ilişkisini inceleyen bu araştırma, tarama modelinde gerçekleştirilmiştir. Bu kapsamda araştırmada toplanan veriler nicel teknikler kullanılarak analiz edilmiştir.

\section{Evren}

Bu çalışmanın evrenini 2016-2017 eğitim-öğretim yılında Ankara ilinin merkez ilçelerindeki resmi ortaokullarda görevli 11.106 kadın öğretmen oluşturmuştur. Araştırma evrenden alınan örneklem üzerinde yürütülmüştür. Örneklem büyüklüğünün belirlenmesinde örneklem büyüklükleri tablosundan yararlanılmış, evreni .05 güvenirlik ve \% 10 hata payı ile 262 kadın öğretmenin temsil edebileceği belirlenmiştir (Balcı, 2005). Ancak anket geri dönüşlerinde yaşanması olası sorunlar nedeniyle araştırmanın uygulama aşamasında 400 öğretmene anket uygulanmış ve bu anketlerden 322'si analiz edilmeye uygun halde geri dönmüştür.

Tablo 1. Katılımcıların Demografik Özellikleri

\begin{tabular}{|c|c|c|c|}
\hline Değişken & Düzey & $N$ & $\%$ \\
\hline \multirow{7}{*}{ Yaş } & $22-26$ & 82 & 25.4 \\
\hline & $27-31$ & 47 & 14.6 \\
\hline & $32-36$ & 28 & 8.0 \\
\hline & $37-41$ & 42 & 13.0 \\
\hline & $42-46$ & 57 & 17.7 \\
\hline & 47 ve üzeri & 66 & 20.3 \\
\hline & Toplam & 322 & 100 \\
\hline \multirow{3}{*}{ Ĕgitim } & Lisans & 285 & 88.5 \\
\hline & Lisansüstü & 37 & 11.5 \\
\hline & Toplam & 322 & 100 \\
\hline \multirow{6}{*}{ Kıdem } & $1-5$ yil & 130 & 40.4 \\
\hline & 6-10 yıl & 17 & 5.3 \\
\hline & $11-15$ yıl & 29 & 9.0 \\
\hline & $16-20$ yll & 40 & 12.4 \\
\hline & 21 ve üstü & 106 & 32.9 \\
\hline & Toplam & 322 & 100 \\
\hline \multirow{3}{*}{ Medeni Durum } & Evli & 209 & 64.9 \\
\hline & Bekâr & 113 & 35.1 \\
\hline & Toplam & 322 & 100 \\
\hline
\end{tabular}


Katılımcıların yaşları incelendiğinde; $22-26$ yaş aralığında olan öğretmen sayısı 82, 27-31 yaş aralığındaki öğretmen sayısı 47, 32-36 yaş aralığındaki öğretmen sayısı 28, 37-41 yaş aralığındaki öğretmen sayısı 42, 42-46 yaş aralığındaki öğretmen sayısı 57 ve 47 ve daha üstü yaşlarda olan öğretmen sayısı ise 66'dır.Katılımcıların 285’i lisans mezunu ve geri kalan 37'si lisansüstü mezunudur. Kıdem bakımından incelendiğinde ise 1-5 yıl arası 130, 6-10 yıl arası 17, 11-15 yıl arası 29, 16-20 yıl arası 40 ve 21 yıl ve daha üstü kıdeme sahip 106 öğretmen araştırmaya katılmıştır. Araştırmaya katılan öğretmenlerin 209'u evli, geri kalan 113'ü bekârdır.

\section{Veri Toplama Araçları İş-Yaşam Dengesi Ölçeği:}

Kadın öğretmenlerin iş-yaşam dengesi algılarını belirlemek amacıyla, Apaydın (2011) tarafından geliştirilen "İ̧̧-Yaşam Dengesi Ölçeği” kullanılmıştır. Ölçme aracında beşli Likert tipi derecelendirme ölçeği (Tam katılıyorum- Hiç katılmıyorum aralığında) sınıflandırılmıştır. Yirmi madde ve dört boyuttan oluşan "İ̧̧-Yaşam Dengesi Ölçeği”nin birinci boyutunu "İ̧̧-Yaşam Uyumu" (6 madde), ikinci boyutunu"Yaşamı İhmal Etme" (6 madde), üçüncü boyutunu“Kendine Zaman Ayırma" ve dördüncü boyutunu "Yaşamın İşten İbaret Olması" (4 madde) oluşturmaktadır. "Hafta sonlarını eşimle ve/veya arkadaşımla birlikte bir şeyler yaparak geçiriyorum" ve "İşime harcadığım zamandan dolayı iş dışındaki etkinlikleri özlüyorum” örnek maddeler arasındadır. İş-yaşam dengesinin orijinal çalışmasında ölçeğin toplam güvenirliği .91, dört alt boyutun güvenirliği ise sırasıyla .88, .81, .77, .79 olarak bulunmuştur (Apaydın, 2011). Mevcut çalışmada toplam güvenirlik .74 bulunmuştur. DFA çalışması LISREL 8.8 versiyonu ile gerçekleştirilmiş ve iş-yaşam dengesinin dört boyutlu yapısının doğrulandığı ve orijinalindeki gibi aynı maddelerin aynı boyutlarda toplandığı görülmüştür. İş-Yaşam Dengesi Ölçeği’nin doğrulayıcı faktör analizinden elde edilen modelin uyum indeksleri $\left[x^{2}=498.07\right.$; $S d=164 ; x^{2} / S d=3.04 ; A G F I=.93 ; G F I=.94 ; N F I=.76 ; C F I=.86$; $I F I=.86 ; R M R=.25 ; R M S E A=.080]$ olarak bulunmuştur. Bulunan uyum indeksi değerleri, modelin iyi uyum verdiğini göstermektedir. 


\section{Bireysel İş Performansı Ölçeği:}

Katılımcıların bireysel iş performansı algı düzeylerini belirlemek üzere, Kirkman ve Rosen (1999) tarafından geliştirilen ve Türkçe uyarlama, geçerlik ve güvenirlik çalışmaları Gürbüz, Erkuş ve Sığrı (2010) tarafından gerçekleştirilen "Bireysel İş Performansı Ölçeği”" kullanılmıştır. 5’li Likert olarak (kesinlikle katılmıyorum, kesinlikle katılıyorum aralığında) hazırlanmış ölçek, tek boyuttan oluşmaktadır. "İş hedeflerime fazlasıyla ulaşırım" ve "Sunduğum hizmet kalitesinde standartlara fazlasıyla ulaştığımdan eminim" ölçekte bulunan örnek maddelerdir. Ölçeğin Türkçe formuna ait Cronbach alfa değeri .89 olarak hesaplanmıştır. Bu araştırma kapsamında ise Cronbach alfa güvenirlik katsayısı .73 olarak bulunmuştur. Ölçeğin yapı geçerliği yürütülen DFA ile test edilmiştir. Yapılan hesaplamalar sonrasında ölçeğin tek boyutlu yapısının doğrulandığ görülmüştür $\left[x^{2}=5.57\right.$; $S d=2 ; x^{2} / S d=2.78 ; A G F I=.94 ; G F I=.99 ; N F I=.90 ; C F I=.95 ; I F I$ $=.95 ; R M R=.041 ; R M S E A=.062]$. Araştırma sonucunda elde edilen uyum iyiliği sonuçları değerlendirildiğinde, Bireysel İş Performansı Ölçeği'nin tek boyutlu formunun geçerli olduğu saptanmıştır.

\section{Bulgular}

Katılımcıların iş-yaşam dengesinin alt boyutları ile iş performansina ilişkin aritmetik puan ortalamaları ve standart sapma puanları ile değişkenler arası korelasyon katsayıları Tablo 1'de sunulmuştur.

Tablo 2. Değişkenlere Ait Betimsel İstatistikler ve Korelasyon Katsayıları

\begin{tabular}{|c|c|c|c|c|c|c|}
\hline & Değişken & 1 & 2 & 3 & 4 & 5 \\
\hline 1 & $\dot{I}_{\text {Iş Performansı }}$ & 1 & & & & \\
\hline 2 & İş-Yaşam Uyumu & $.18^{* *}$ & 1 & & & \\
\hline 3 & Yaşamı İhmal Etme & $.33^{* *}$ & $.54^{* *}$ & 1 & & \\
\hline 4 & Kendine Zaman Ayırma & .08 & $.56^{* *}$ & $.52^{* *}$ & 1 & . \\
\hline 5 & Yaşamın İşten İbaret Olması & $.14^{*}$ & .58 & $.26^{* *}$ & $.24^{* *}$ & 1 \\
\hline & Ortalama & 4.01 & 3.26 & 3.41 & 2.45 & 2.95 \\
\hline & Standart Sapma & .64 & .55 & .46 & .87 & .57 \\
\hline & $\mathrm{N}=322 ;{ }^{*} p<.01 ;{ }^{* *} p<.05$ & & & & & \\
\hline
\end{tabular}


Tablo 1'den de izlenebileceği gibi katılımcıların "İş Performansı" puan ortalamaları 4.01 ( $S D=.64)$, "İ̧̧-Yaşam Uyumu" puan ortalamaları $3.26(S D=.55)$, "Yaşamı İhmal Etme" puan ortalaması 3.41 (SD =.46), "Kendine Zaman Ayırma" puan ortalaması $2.45(\mathrm{SD}=.87)$ ve "Yaşamın İşten İbaret Olması" puan ortalaması 2.95’tir $(S D=.57)$. "İ̧̧ Performansı" puan ortalaması 'yüksek' düzeyde, "İ̧̧-Yaşam Uyumu” puan ortalaması 'yüksek' düzeyde, "Yaşamı İhmal Etme”, "Kendine Zaman Ayırma" ve "Yaşamın İşten İbaret Olması" puan ortalamaları 'orta' düzeydedir.

Tablo 1'den de izlenebileceği üzere iş performansının İş-Yaşam Dengesi Ölçeği’nin “İş-Yaşam Uyumu” boyutu ile pozitif yönlü, düşük ve anlamlı bir ilişki ( $r=.18$; $p<.05)$, "Yaşamı İhmal Etme" boyutu ile pozitif yönlü, orta ve anlamlı bir ilişki ( $r=.33$; $\mathrm{p}<.05)$, "Yaşamın İşten İbaret Olması" boyutu ile pozitif yönlü, düşük ve anlamlı bir ilişki $(r=.14 ; p<.01)$ olduğu görülmüştür.

İ̧̧-yaşam dengesi boyutlarının iş performansının anlamlı bir yordayıcısı olup olmadığı regresyon analizi ile çözümlenmiştir. Sonuçlar Tablo 2'de sunulmuştur.

Tablo 3. İş-Yaşam Dengesi Boyutlarının İşs Performansını Yordamasına İlişkin Regresyon Sonuçları

\begin{tabular}{lccccc}
\hline $\begin{array}{l}\text { (Bağımlı Değişken=İ̧ Performansı) } \\
\text { Değişken }\end{array}$ & $\boldsymbol{B}$ & $\begin{array}{c}\text { Standart } \\
\text { Hata } \boldsymbol{B}\end{array}$ & $\boldsymbol{\beta}$ & $\boldsymbol{t}$ & $\boldsymbol{p}$ \\
\hline İş-Yaşam Uyumu & .08 & .08 & .07 & 1.06 & .29 \\
\hline Yaşamı İhmal Etme & .51 & .09 & .36 & 5.40 & $.00^{*}$ \\
\hline Kendine Zaman Ayırma & -.13 & .05 & -.17 & -2.53 & $.01^{*}$ \\
\hline $\begin{array}{l}\text { Yaşamın İşten İbaret } \\
\text { Olması }\end{array}$ & .09 & .06 & .08 & 1.48 & .14 \\
\hline
\end{tabular}

$\mathrm{R}=.363 ; \mathrm{R}^{2}=.132 ; \mathrm{F}=12.007 ; \mathrm{p}=.000 * ;{ }^{*} \mathrm{p}<.05$

Tablo 2'de görüldüğü gibi “İş-Yaşam Dengesi Ölçeği” boyutları ile iş performansı arasında orta düzeyde ve anlamlı bir ilişki bulunmaktadır $\left(R=.363 ; R^{2}=.132 ; p<.05\right)$. Bu bulgulara göre iş performansının \%13'ü “İş-Yaşam Dengesi” boyutları tarafından 
açıklanmaktadır. Standardize edilmiş regresyon katsayısına göre (B) "İş-Yaşam Dengesi”nin "Yaşamı İhmal Etme" (t=5.40, p<.05) ve "Kendine Zaman Ayırma" ( $t=-2.53, p<.05)$ boyutları iş performansının anlamlı yordayıcılarıdır.

\section{Tartışma, Sonuç ve Öneriler}

Uddin, Mamun, Hoque ve Uddin (2013) tarafindan özel okulda görevli kadın öğretmenler üzerine Bangladeş’te yapılan çalışmada, \%78'inin iş-yaşam dengesini sağlayamadıklarını ifade ettikleri görülmektedir. Buna bağlı olarak da \%26’sının işten ayrılmak istediğinin altını çizen bu çalışma iş-yaşam dengesinin iş performansını etkilediğini gösteren bir çalışmadır.

Maeran, Pitarelli ve Cangiano (2013) tarafından öğretmenlerin iş-yaşam dengesi ile iş doyumu üzerine İtalya'da yapılan çalışma, kadın öğretmenlerin işleriyle daha meşgul, bununla birlikte öğretmenliğin anneler için stresli bir meslek ve iş ile aile arasındaki ilişki açısından belirgin bir sürtüşme kaynağı olduğunu göstermiştir. Çalışmada öğretmenlerin iş-yaşam çatışması düzeylerinin öğretmenlik tecrübelerine ve görev yaptıkları okulun kademesine bağlı olarak da değiştiği ortaya konmuştur. Nitekim bulgulara göre, ilköğretim okullarında örgüt yapısının ve eğitim ihtiyaçlarının farklı olmasının bir sonucu olarak iş-yaşam dengesizliğinin daha da belirginleştiği, öte yandan bir öğretmenin ne kadar çok deneyimi varsa, ailedeki sorumluluklarını olumsuz etkilemeden işinin talep ve gereksinimlerini yerine getirme ve iki alan arasında uyum sağlama yetkinliğinin de o kadar yüksek olduğu görülmektedir. Bu bağlamda, mesleğe yeni girmiş, yeni evlenmiş ve yeni çocuk sahibi olmuş öğretmenlerde işyaşam çatışmasının arttığı gözlemlenmiştir.

Bostancioğlu'nun (2014), İstanbul'da öğretmenler üzerinde yaptığı "iş-yaşam dengesi ve iş-yaşam dengesinin çalışan verimliliği üzerindeki etkileri” araştırmasındaki bulgulara göre de iş-yaşam dengesi, cinsiyete göre kadın öğretmenler lehine farklılaşmaktadır. $\mathrm{Bu}$ durumun öğretmenlerin esnek çalışma saatlerinin olması, diğer mesleklere göre kendilerine ayıracak daha fazla vakitlerinin olması ve özellikle manevi (insanlara hizmet etme arzusu, topluma faydalı 
olma isteği, çocukları sevmek gibi) doyumu yüksek bir mesleğe sahip olmalarından kaynaklandığı değerlendirilmiştir.

$\mathrm{Bu}$ araştırmada kadın öğretmenlerin iş-yaşam dengesi ile iş performansı ilişkisi, Ankara ili resmi ortaokullarında görev yapmakta olan 322 kadın öğretmenin görüşlerine göre incelenmiştir. Katılımcllardan toplanan veriler aritmetik ortalama ve standart sapma gibi betimsel istatistiklerin yanı sıra, doğrulayıcı faktör analizi (DFA), Pearson korelasyon ve regresyon analizi ile çözümlenmiştir.

Bulgular, kadın öğretmenlerin iş performansı puan ortalamasının 'yüksek' düzeyde olduğuna işaret etmektedir. Bu çerçevede, kadın öğretmenlerin işleri ile ilgili sorumluluklarını yüksek düzeyde yerine getirdiklerini ve tamamladıklarını düşündükleri görülmüştür.

Kadın öğretmenlerin "İş-Yaşam Uyumu” puan ortalaması 'yüksek' düzeyde, "Yaşamı İhmal Etme", "Kendine Zaman Ayırma" ve "Yaşamın İşten İbaret Olması” puan ortalamaları 'orta' düzeydedir. $\mathrm{Bu}$ çerçevede, iş-yaşam uyumunu sağlayabildiklerini düşünen kadın öğretmenlerin buna karşın yaşamı ihmal ettikleri, kendilerine yeterince zaman ayıramadıkları ve kısmen yaşamlarını da işten ibaret gördükleri anlaşılmaktadır.

Kadın öğretmenlerin iş performansı ile "İş-Yaşam Dengesi Ölçeğì"nin "İş-Yaşam Uyumu", "Yaşamı İhmal Etme" ve "Yaşamın İşten İbaret Olması" boyutları arasında pozitif yönlü ilişki olduğu görülmüştür. Bu durumda iş-yaşam uyumunu sağlayabilen, okul yaşamı dışında kalan yaşamını ihmal eden ya da yaşamını sadece iş hayatından ibaret sayan kadın öğretmenlerin iş performanslarının daha yüksek olduğu görülmektedir. İş hayatı dışında kalan yaşamını ihmal etmek zorunda kalan ya da tercihinde bulunan kadın öğretmenlerin ne kadar mutlu veya sağlıklı bir hayatı olduğu tartışılmalıdır. Bir diğer husus da kadın öğretmenin yaşamının işten ibaret olabilmesinin ne kadar mümkün olabileceğidir ki, bu da tartışlabilecek bir konudur.

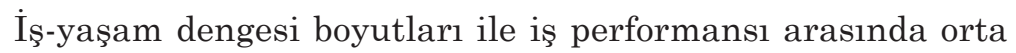
düzeyde ve anlamlı bir ilişki bulunmaktadır. Bulgulara göre iş 
performansının \%14'ü iş-yaşam dengesi boyutları tarafından açıklanmaktadır. Standardize edilmiş regresyon katsayısına göre $(\beta)$ işyaşam dengesinin "Yaşamı İhmal Etme" ve "Kendine Zaman Ayırma" boyutları iş performansının anlamlı yordayıcılarıdır.

Çalışmalar ışığında kadın öğretmenlerin iş-yaşam dengesini kurmakta zorlandıkları ve bunun iş performanslarını etkilediği; bu kapsamda okul sorumlulukları ile okul dışı yaşamları arasında sıkıştıkları görülmektedir.

Kadın öğretmenlerin iş-yaşam dengesini sağlamaları, iş performanslarını arttırmaları ve daha etkili bir öğretmen olabilmeleri için; ders yüklerinin optimize edilmesi, sınıf mevcutlarının azaltılması, özel eğitime ihtiyaç duyan çocuklar için sağlanan desteklerin geliştirilmesi, planlama ve hazırlık çalışmaları için zaman arttırılması, öğretim dışı taleplerin (idari görevler, kırtasiye işleri) azaltılması gibi öneriler sunulabilir.

\section{Kaynakça}

Altun-Dilek, S. \& Yılmaz, K. (2016). Öğretmenlerin işkoliklik eğilimleri ile iş-yaşam dengeleri, e-Kafkas Eğitim Araştırmaları Dergisi, 3(1), 36-55.

Apaydın, Ç. (2011). Öğretim üyelerinin işe bağımlılık düzeyi ile iş-yaşam dengesi ve iş-aile yaşam dengesi arasındaki ilişki (Yayımlanmamış Doktora Tezi), Ankara Üniversitesi, Eğitim Bilimleri Enstitüsü, Ankara.

Bingöl, D. (2006). İnsan Kaynakları Yönetimi, Beta BasımYayım Dağıtım A.Ş., İstanbul.

Brown, P. (2004). Promoting work / life balance in a "hurry culture": Issues and challenges. Professorial Lecture, Griffith University, Australia. [Çevrim-içi: https://www.griffith.edu.au/_data/assets/pdf_file/0003/314589/ brownp04.pdf Erişim: 17 Haziran 2016].

Burke, R. J. (2000). Workaholism in organizations: The role of personal beliefs and fears. Anxiety, Stress \& Coping, 13(1), 53-64.

Chiu- Kou, S. (2004). The Linkage of Job Performance To Goal Setting, Work Motivation, Team Building, and Organizational Commitment in The High- Tech Industry in Taiwan, Yayınlanmamış Doktora Tezi, H. Wayne Huizenga School of Business and Entrepreneurship Nova Southeastern University. 
Cinamon, R. G. \& Rich, Y. (2002). Gender differences in the importance of work and family roles: Implications for work-family conflict, Sex Roles, 47(11/12), 531-541.

Day, C., Stobart, G., Sammons, P., Kington, A., Gu, Q., Smees R., \& Mujtaba T. (2006). Variations in teachers' work, lives and effectiveness, Research Report, Department for Education and Skills, Nottingham: DfES Publications. [Çevrim-içi: http://dera.ioe.ac.uk/6405/1/rr743.pdf, ErişimTarihi: 16 Haziran 2017].

Duxbury, L. \& Higgins, C. (2003). Work-life conflict in Canada in the new millennium, A status report. Ottawa: Health Canada. [Çevrim-içi: http://publications.gc.ca/collections/Collection/H72-21-186-2003E.pdf, ErişimTarihi: 14 Haziran 2017].

Erben, G. S. \& Ötken, A. B. (2014). Paternalist liderlik ve işe ilişkin iyilik ilişkisinde iş-yaşam dengesinin rolü, Yönetim ve Ekonomi Araştırmaları Dergisi, 12(22), 103-121.

Eren, S. S. \& Hayatoğlu, Ö. (2011), Etik iklimin satış elemanlarının iş tutumlarına ve iş performanslarına etkisi: ilaç sektöründe bir uygulama, Zonguldak Karaelmas Üniversitesi Sosyal Bilimler Dergisi, 7(14), 110-128.

Froese-Germain, B. (2014). Work-life balance and the Canadian teaching profession. Research \& Information, Canadian Teachers' Federation. [Çevrim-içi: https://www.ctf-fce.ca/Research-Library/Work-lifeBalancea ndtheCanadianTeachingProfession.pdf, ErişimTarihi 16 Haziran 2017].

Greenglass, E., Burke, R.J. \& Konarski, R. (1998). Components of burnout, resources and gender-related differences, Journal of Applied Social Psychology, 28, 1088-1106.

Guest, D. E. (2002), Perspectives on the study of work-life balance, Social Science Information, 41, 255-279.

Kapız, S. Ö. (2002). İş aile yaşamı dengesi ve dengeye yönelik yeni bir yaklaşım: Sınır teorisi, Dokuz Eylül Üniversitesi Sosyal Bilimler Enstitüsü Dergisi, 4(1), 139-153.

Karaman, N. (2015). Refah rejimleri sınıflandırmaları ekseninde Türkiye'de iş-aile yaşamını uyumlaştırma politikaları ve kadın istihdamı (Yayımlanmamış Yüksek Lisans Tezi), Gazi Üniversitesi, Sosyal Bilimler Enstitüsü, Ankara.

Koray, N. (2016). Kadınların çalışma hayatındaki iş yaşam dengesi sorunları ve Avrupa Birliği - Türkiye düzenlemeleri (Yayımlanmamış Yüksek Lisans Tezi), Yalova Üniversitesi, Sosyal Bilimler Enstitüsü, Yalova.

Küçükusta, D. (2007). Konaklama işletmelerinde iş-yaşam dengesinin çalışma yaşamıkalitesi üzerindeki etkisi (Yayımlanmamış Doktora Tezi), Dokuz Eylül Üniversitesi, Sosyal Bilimler Enstitüsü, İzmir. 
Lewis, S., Gambles, R. \& Rapoport, R. (2007). The constraints of "work- life balance" approach: An international perspective, The International Journal of Human Resource Management, 18(3), 360-373.

Maeran, R., Pitarelli, F., \&Cangiano, F. (2013). Work-life balance and job satisfaction among teachers, Interdisciplinary Journal of Family Studies, 18(1), 51-72.

McIntosh, S. (2003). Work-life balance: How life coaching can help, Business Information Review, 20(4), 181-189.

Özkul, R. (2014). Ortaokul öğretmenlerinde iş-aile çatışması ve yaşam doyum düzeyleri (Yayımlanmamış Yüksek Lisans Tezi), İnönü Üniversitesi, Ĕ̈itim Bilimleri Enstitüsü, Malatya.

Polat, Ş. (2017), İş özellikleri, iş-yaşam dengesi ve meslekten ayrılma niyeti arasındaki ilişkilerin öğretmen görüşlerine göre incelenmesi (Yayımlanmamış Doktora Tezi), Hacettepe Üniversitesi, Ankara.

Saeed, K., \& Farooqi, Y. A. (2014). Examining the relationship between work life balance, job stress and job satisfaction among university teachers (A case of University of Gujrat), International Journal of Multidisciplinary Sciences and Engineering, 5(6), 9-15.

Savcı, İ. (1999). Çalışma yaşamı ile çalışma dışı yaşam alanlarının ilişkisi üzerine kuramsal yaklaşımlar, Ankara Üniversitesi Siyasal Bilgiler Fakültesi Dergisi, 54(4), 145-166.

Senthilkumar, K. G., Chandrakumaramangalam S., \&Manivannan, L. (2012). An empirical study on teaching professionals' work-life balance in higher learning institutions with special reference to Namakkal district, Tamilnadu, Bonfring International Journal of Industrial Engineering and Management Science, 2(3), 38-41.

Shmailan, A. (2016). The relationship between job satisfaction, job performance and employee engagement: an explorative study, Issues in Business Management and Economics Original Research Article, 4(1), 1-8.

Uddin, M.A., Abdullah Mohammad Ahshanul-Mamun, A.M., Hoque, N. \& Uddin, M.S. (2013). Work-life balance: a study on femaleteachers of private education institutions of Bangladesh, European Journal of Business and Management, 5(13), 10-17.

Yıldız, S., Savcı, G. \& Kapu, H. (2014). Motive edici faktörlerin çalışanların iş performansına ve işten ayrılma niyetine etkisi, Yönetim ve Ekonomi, 21 (1), 233-249. 